\title{
First record of Andinia panica (Orchidaceae) from Colombia
}

\author{
Marta Kolanowska ${ }^{1,2^{*}}$, Ramiro Medina Trejo ${ }^{3} \&$ Dariusz L. Szlachetko ${ }^{4}$
}

${ }^{1}$ Department of Geobotany and Plant Ecology, Faculty of Biology and Environmental Protection, University of Lodz, Banacha 12/16, 90-237 Łódź, Poland

${ }^{2}$ Global Change Research Centre AS CR, Belidla 986/4a, 60300, Brno, Czech Republic

${ }^{3}$ Sibundoy Valley, Alto Putumayo, Colombia

${ }^{4}$ Department of Plant Taxonomy and Nature Conservation, Faculty of Biology, University of Gdansk, Wita Stwosza 59, 80-308 Gdańsk, Poland

* corresponding author (e-mail: marta.a.kolanowska@gmail.com)

\begin{abstract}
Andinia panica, previously known exclusively from the type locality in Ecuador, is reported for the first time from Colombia. Characteristic of population found in Valle de Sibundoy is provided together with photographs of the specimen and information about its habitat. Moreover, the comparative morphology of species included in Andinia subgenus Minuscula, is presented together with the key to species identification.
\end{abstract}

Key words: biodiversity, Neotropics, Pleurothallidinae

\section{Introduction}

The taxonomy of the orchid genus Andinia (Luer) Luer was confusing for years and species recently embedded in this taxon (Wilson et al. 2017) were previously classified in, i.a., Lepanthes Sw., Pleurothallis R. Br., Salpistele Dressler, Lueranthos Szlach. \& Marg., Masdevalliantha (Luer) Szlach. \& Marg., Xenosia Luer, and Neooreophilus Archila. In the broad concept Andinia includes vegetatively variable species with caespitose or rhizomatous habit, usually producing successively-flowered inflorescences. Their leaves are herbaceous to thickly coriaceous. The flower morphology differs significantly between the species groups. The column foot is observed exclusively in Andinia subgen. Masdevalliantha (Luer) Karremans \& Mark Wilson. Andinia subgen. Brachycladium (Luer) Karremans \& S.Vieira-Uribe includes pendent plants with leaves appearing alternately and often overlapping. Three other subgenera, Aenigma, Andinia and Minuscula, are separable by the lip middle lobe form (sometimes transformed into an appendix or appendix-like structure) and the lip lateral lobes position (subtending the column vs frontal).

Among over 70 Andinia species, just three, A. hystri$\cos a$ (Luer) Pridgeon \& M. W. Chase, A. panica (Luer
\& Dalström) Pridgeon \& M. W. Chase, and A. trimytera (Luer \& R. Escobar) Pridgeon \& M.W.Chase, were assigned by Wilson et al. (2017) to the subgenus Minuscula Karremans \& Mark Wilson. Plants included in this taxon are characterized by the repent-ascending habit, coriaceous leaves, loose inflorescence, spiculate ovary, 3-lobed lip with more or less triangular, conspicuous, lateral lobes and apical anther and stigma. Until now, two of these three Andean species, A. hystricosa and A. trimytera, were found in Colombia.

The recent studies conducted in Valle de Sibundoy revealed the presence of the third species of subgen. Minuscula in Colombia - A. panica.

\section{Material and methods}

Studies on the orchid flora of Sibundoy Valley have been conducted since 2012. Plant material found during field excursions and herbarium specimens deposited in COL and PSO were compared with type material and protologues. Both vegetative and generative characters of each plant were examined (leaves, inflorescence architecture, shape and size of the floral bracts, flower morphology and gynostemium structure). The comparative research was conducted in: AMES, B, BM, C, CHOCO, CUVC, E, F, FLAS, FMB, HUA, JAUM, 
K, LLANOS, LPB, MA, MO, NHN, NY, P, PMA, R, RENZ, VALLE, and W (Thiers 2018).

\section{Results}

\subsection{Species characteristic}

Andinia panica (Luer \& Dalström) Pridgeon \& M. W. Chase, Lindleyana 16(4): 251. 2001. $\equiv$ Pleurothallis panica Luer \& Dalström, Monogr. Syst. Bot. Missouri Bot. Gard. 61(3): 6. 1996. Type: Ecuador. Sucumbíos: epiphytic in forest between La Bonita and Rosa Florida, alt. 1600-2000 m, 14 Mar 1996. S. Dalström, S. Ingram \& K. Ferrell-Ingram 2123 (Holotype: MO).

Plant small, caespitose. Ramicauls slender, erect, 1-1.5 mm long, enclothed by 2 thin sheaths. Leaf erect, coriaceous, up to $7 \mathrm{~mm}$ long, $2 \mathrm{~mm}$ wide, elliptic, apex dentate, base cuneate. Inflorescence 2-flowered raceme, flowers produced successively; peduncle $5 \mathrm{~mm}$ long, slender. Floral bract $1 \mathrm{~mm}$ long, obliquely ovate, acute. Pedicel $2 \mathrm{~mm}$ long, ovary $0.8 \mathrm{~mm}$ long, spiculate. Flower greenish-yellow with yellow-red lip, sepals carinate-spiculate externally. Dorsal sepal $3.1 \mathrm{~mm}$ long, $1.5 \mathrm{~mm}$ wide, ovate, obtuse, 3-veined. Lateral sepals $3.5 \mathrm{~mm}$ long, $1.2 \mathrm{~mm}$ wide, connate in the basal $1.8 \mathrm{~mm}$, oblong, rounded at the apices, 2-veined, pubescent. Petals $1.5 \mathrm{~mm}$ long, $0.5 \mathrm{~mm}$ wide, oblongovate, obtuse, 1-veined. Lip hinged to the column foot base, 3-lobed, $1 \mathrm{~mm}$ long, $2.5 \mathrm{~mm}$ wide, middle lobe triangular, lateral lobes obliquely ovate, acute, lip margins crenate-denticulate, papillose-verrucose; disc with a shallow, central callus. Gynostemium ca. $1.2 \mathrm{~mm}$ long, stout, anther and rostellum apical.

Representative specimen: Colombia. Dept. Putumayo. Valle de Sibundoy. „La Palma”. Alt. ca. 2550 m. 2 August 2018. R. Medina T. 1124 (JAUM!) (Fig. 1).

Distribution, habitat and ecology: Colombian and Ecuadorian populations of $A$. panica are located about $100 \mathrm{~km}$ apart from each other (Fig. 2). This species grows epiphytically in the Colombian north-Andean montane forest at the altitude higher of about $500 \mathrm{~m}$ than it was initially found in Ecuador. The type specimen of A. panica was found in flower in March 1996 (Luer 1996), the Colombian population flowers in August.

\subsection{Taxonomic notes}

The three species included in Andinia subgenus Minuscula differ in vegetative and floral characters (Table 1). Both in A. hystricosa and A. trimytera, the leaf apex is apiculate, while in Andinia panica it is

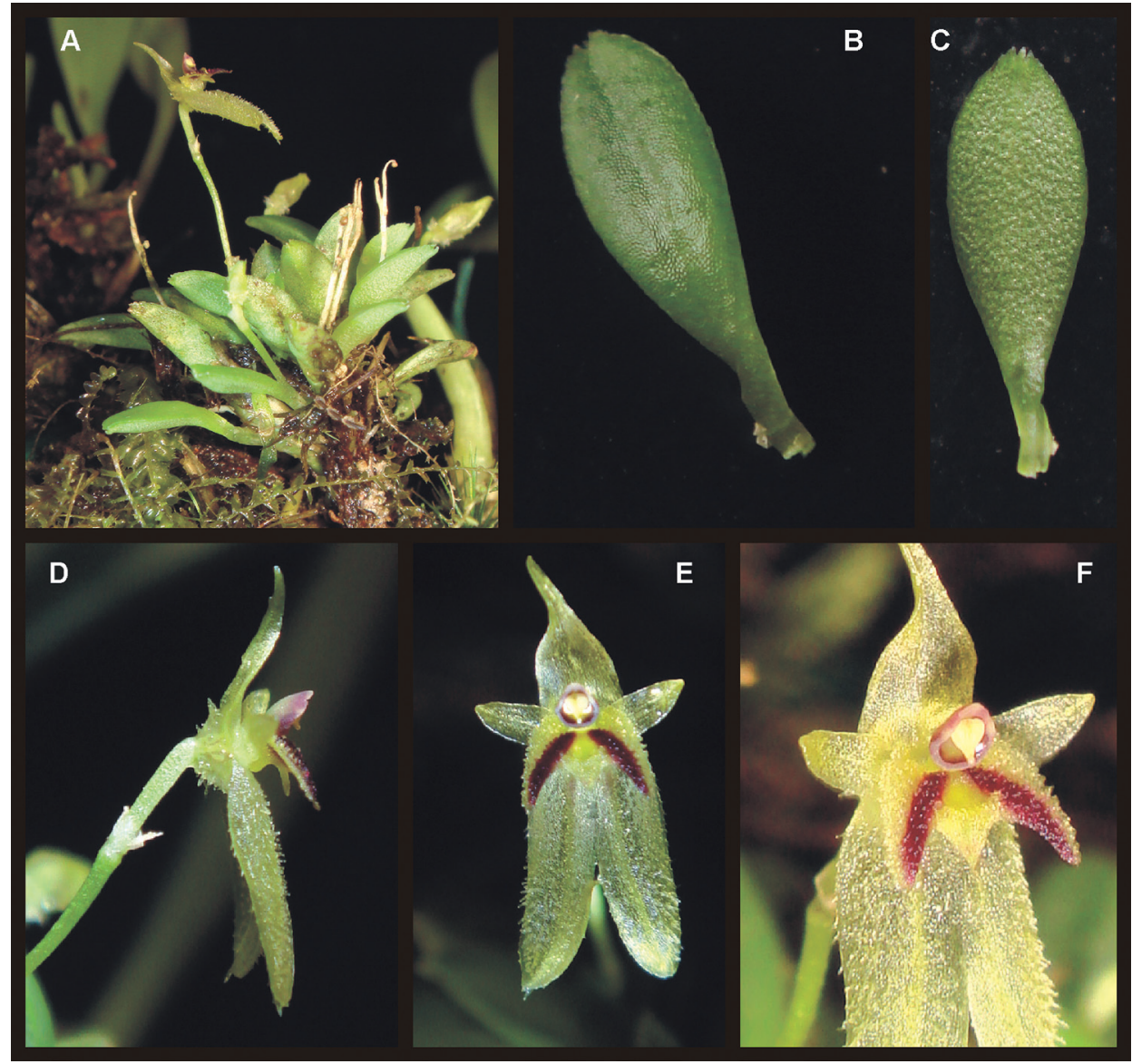

Fig. 1. Colombian specimen of Andinia panica

Explanations: A - habit, B-C - leaf, D - flower, side view, E - flower, front view, F - petals, lip and gynostemium closeup 


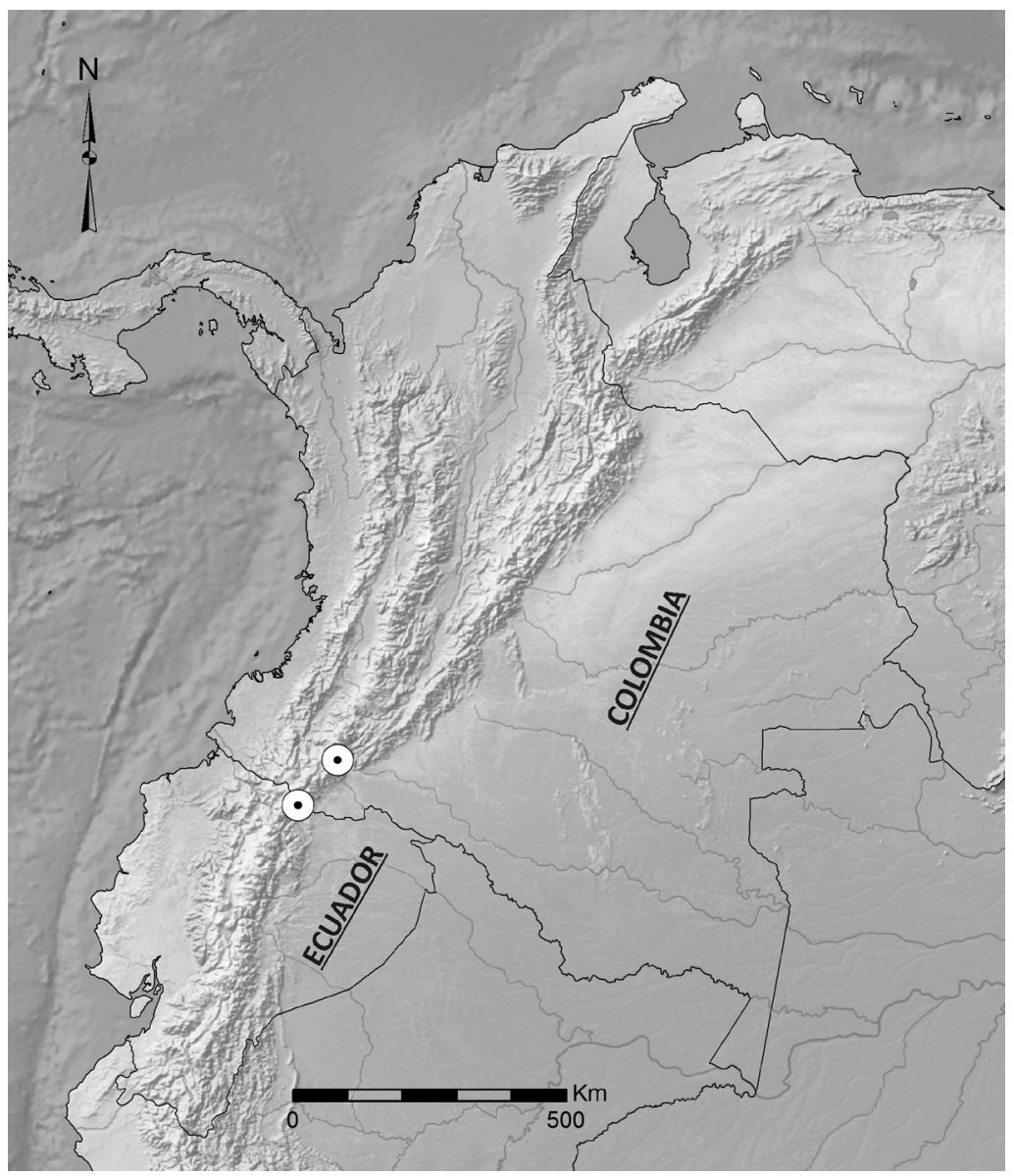

Fig. 2. Distribution of Andinia panica

dentate. Flowers of $A$. trimytera are generally smaller than in other two species (sepals 2.1-2.7 mm vs 3.0$4.5 \mathrm{~mm}$ ) and its petals are microscopic, only about $0.1 \mathrm{~mm}$ long. Andinia hystricosa and A. panica can be easily distinguished based on petal form (oblong-ovate, subacute to obtuse in A. panica vs narrowly ovate, acute, long-acuminate in $A$. hystricosa). Moreover, unlike in $A$. panica, the lip lateral lobes of $A$. hystricosa are curved

Table 1. Comparative morphology of Andinia hystricosa, A. panica, and A. trimytera

\begin{tabular}{|c|c|c|c|}
\hline & A. hystricosa & A. panica & A. trimytera \\
\hline Leaves & $\begin{array}{l}8-18 \times 2-4.5 \mathrm{~mm} \text {, elliptic- } \\
\text { obovate, apex apiculate }\end{array}$ & $\begin{array}{l}5-7 \times 2-3 \mathrm{~mm} \text {, elliptic, obtuse, } \\
\text { apex dentate }\end{array}$ & $\begin{array}{l}4-6 \times 2.5-3.5 \mathrm{~mm} \text {, broadly } \\
\text { elliptic, apex apiculate }\end{array}$ \\
\hline Dorsal sepal & $\begin{array}{l}3.5 \times 1.25 \mathrm{~mm} \text {, ovate, acute, } \\
\text { carinate-spiculate }\end{array}$ & $\begin{array}{l}3 \times 1.5-2 \mathrm{~mm} \text {, ovate to ovate- } \\
\text { triangular, acute, carinate- } \\
\text { spiculate }\end{array}$ & $\begin{array}{l}2.1 \times 1.2 \mathrm{~mm} \text {, ovate, more or } \\
\text { less compressed at the acute, } \\
\text { recurved apex, subcarinate }\end{array}$ \\
\hline Lateral sepals & $\begin{array}{l}4 \times 1.25 \mathrm{~mm} \text {, ovate, oblique, } \\
\text { acute, connate for } 1.5 \mathrm{~mm}, \\
\text { carinate-spiculate }\end{array}$ & $\begin{array}{l}3.5-4.5 \times 1.2-1.5 \mathrm{~mm} \text {, oblong- } \\
\text { ovate, obtuse, connate for ca. } \\
1.5-1.8 \mathrm{~mm} \text {, carinate-spiculate, } \\
\text { pubescent }\end{array}$ & $\begin{array}{l}2.7 \mathrm{~mm} \times 1 \mathrm{~mm} \text {, ovate, oblique, } \\
\text { acute, connate for } 1 \mathrm{~mm}, \\
\text { carinate-spiculate }\end{array}$ \\
\hline Petals & $\begin{array}{l}2.75 \times 0.5 \mathrm{~mm} \text {, narrowly ovate, } \\
\text { acute, long-acuminate }\end{array}$ & $\begin{array}{l}1.5-1.75 \times 0.5-0.75 \mathrm{~mm} \text {, oblong- } \\
\text { ovate, subacute to obtuse }\end{array}$ & $\begin{array}{l}\text { microscopic, ca. } 0.1 \mathrm{~mm} \text { long, } \\
\text { oblong, obtuse }\end{array}$ \\
\hline Lip & $\begin{array}{l}\text { transversely } 3 \text {-lobed, } 1 \times \\
1.75 \text { mm, margin crenulate- } \\
\text { denticulate, subverrucose; } \\
\text { middle lobe narrowly triangular, } \\
\text { lateral lobes obliquely ovate, } \\
\text { uncinate, curved forward, acute; } \\
\text { disc with a concave callus in the } \\
\text { centre }\end{array}$ & $\begin{array}{l}\text { transversely } 3 \text {-lobed, } 1 \times 2.5 \text { - } \\
2.75 \text { mm, margin crenulate- } \\
\text { denticulate, papillose-verrucose, } \\
\text { middle lobe triangular, lateral } \\
\text { lobes obliquely ovate, uncinate; } \\
\text { disc with flat, shallow callus in } \\
\text { the centre }\end{array}$ & $\begin{array}{l}\text { transversely } 3 \text {-lobed, } 1.5 \times \\
1.5 \mathrm{~mm} \text {, margin crenulate- } \\
\text { denticulate, papillose-verrucose, } \\
\text { middle lobe triangular, lateral } \\
\text { lobes obliquely triangular; disc } \\
\text { with a shallow callus in the } \\
\text { centre }\end{array}$ \\
\hline
\end{tabular}


forward. The difference is observed also in the number of lateral sepal veins ( 2 in A. panica, 3 in A. hystricosa). The key to identification of Andinia subgenus Minuscula species is provided.

\subsection{Key to Andinia subgen. Minuscula}

1. Petals microscopic, less than $0.2 \mathrm{~mm}$ long A. trimytera

1 * Petals not microscopic, at least $1.5 \mathrm{~mm}$ long 2
2. Petals 1.5-1.75 mm long, oblong-ovate, subacute to obtuse A. panica 2* Petals ca. $2.75 \mathrm{~mm}$ long, narrowly ovate, acute, long-acuminate A. hystricosa

Acknowledgments. The curators and staff of the cited herbaria are thanked for their kind hospitality and assistance during visits. This research was supported by the grant No. 14-36098G of the Grantová Agentura České Republiky.

\section{References}

Luer C. A. 1996. Icones Pleurothallidinarum XIV. Systematics of Draconanthes, Lepanthes subgenus Marsipanthes and subgenus Lepanthes of Ecuador; Addenda to Brachionidium, Lepanthes subgen. Brachycladium, Platystele, Pleurothallis subgen. Aenigma and subgen. Ancipitia. Monogr. Syst. Bot. Missouri Bot. Gard. 61: 1-286.

Thiers B. 2018. Index Herbariorum: A global directory of public herbaria and associated staff. New York Bo- tanical Garden's Virtual Herbarium. http://sweetgum. nybg.org/science/ih/.

Wilson M., Frank G. S., Jost L.,Pridgeon A. M., VieiraUribe S. \& Karremans A. P. 2017. Phylogenetic analysis of Andinia (Pleurothallidinae; Orchidaceae) and a systematic re-circumscription of the genus. Phytotaxa 295(2): 101-131. 